\title{
Susceptibility of Micro-organisms to Active Oxygen Species: Sensitivity to the Xanthine-oxidase-mediated Antimicrobial System
}

\author{
By YOSHITAKA YAMADA, 1.2* HAJIME SAITO, ${ }^{2}$ HARUAKI TOMIOKA \\ AND JOJI JIDOI ${ }^{1}$ \\ Department of Dermatology. ${ }^{1}$ and Department of Microbiolog. and Immunology.? \\ Shimane Medical University, Izumo 693. Japan
}

(Received 30 September 1986; revised 18 February 1987)

\begin{abstract}
Xanthine oxidase with acetaldehyde as substrate (the XOA system) generated superoxide anion and hydrogen peroxide, but this system had only weak bactericidal activity. Addition of $\mathrm{Fe}^{2+}$ and EDTA to the XOA system (XOA-Fe-EDTA system) increased bactericidal activity against Staphylococcus aureus, Escherichia coli, Listeria monocytogenes and Salmonella typhimurium, although both Mycohacterium tuberculosis and Candida alhicans remained highly resistant. Catalase $\left(\mathrm{H}_{2} \mathrm{O}_{2}\right.$ scavenger) and mannitol ( $\mathrm{OH}$ scavenger) almost completely inhibited the bactericidal activity of the XOA-Fe EDTA system whereas SOD $\left(\mathrm{O}_{2}^{-}\right.$scavenger) was less inhibitory. Azide ( ${ }^{1} \mathrm{O}_{2}$ scavenger) caused no such inhibition. The results suggest the possible role of $\mathrm{OH}, \mathrm{H}_{2} \mathrm{O}_{2}$ and $\mathrm{O}_{2}^{-}$in the XOA-Fe-EDTA-mediated antimicrobial system, as effector molecules. There was no correlation between resistance of a given bacterium to active oxygen and the level of endogenous active oxygen-scavengers.
\end{abstract}

\section{INTRODUCTION}

Active oxygen species (Chance et al., 1979; Krinsky, 1974; Rosen \& Klebanoff, 1979 h), the halogenation reaction (Klebanoff, 1967, 1968, 1982a, $b$; Klebanoff \& Shepard, 1984), longchain fatty acids (Kanai \& Kondo, 1979: Saito et al., 1984), and some cationic antibacterial peptides (Elsbach \& Weiss, 1983: Pabst \& Johnston, 1980) play important roles in the expression of microbicidal activity by macrophages and polymorphonuclear leucocytes. In particular, active oxygen species such as $\mathrm{O}_{2}^{-}, \mathrm{H}_{2} \mathrm{O}_{2},{ }^{\circ} \mathrm{OH}$ and ${ }^{1} \mathrm{O}_{2}$ generated by these phagocytic cells in response to triggering by certain membrane perturbations and by some membrane activators (Dath \& Karnovsky, 1975: Nathan. 1982; Oyanagui, 1981) exhibit a potent antimicrobial activity (Babior et al. 1973). These active oxygen species can also be produced in a cell-free system consisting of xanthine oxidase (XO) and acetaldehyde (or xanthine) as a substrate (Rosen \& Klebanoff, $1979 a, 1981$ ). The XOA system produces $\mathrm{O}_{2}^{-}$, and $\mathrm{H}_{2} \mathrm{O}_{2}$ by spontaneous dismutation of the $\mathrm{O}_{2}^{-}$. More toxic active oxygen radicals, ${ }^{\circ} \mathrm{OH}$ and ' $\mathrm{O}_{2}$ (Hoidal et al.. 1979: Weiss et al., 1977), are thought to emerge by the Haber-Weiss reaction: $\mathrm{O}_{2}^{-}+\mathrm{H}_{2} \mathrm{O}_{2} \rightarrow$ $\mathrm{OH}+{ }^{1} \mathrm{O}_{2}+\mathrm{OH}^{-}$. However, this reaction is very slow under physiological conditions (Halliwell, 1976), and the amount of ${ }^{\circ} \mathrm{OH}$ and ${ }^{\prime} \mathrm{O}_{2}$ generated spontaneously in the XOA system is negligible. Halliwell $(1978 a, b)$ reported that the addition of chelated iron such as Fe ${ }^{2+}$ EDTA to the XOA system (XOA Fe EDTA system) resulted in a marked increase in the generation of $\mathrm{OH}$ and ${ }^{\prime} \mathrm{O}_{2}$. The XOA-Fe EDTA system is much more toxic to some bacteria, such as Legionella pneumophila and Staphylococcus aureus, than is the XOA system alone (Locksley et al., 1982: Rosen \& Klebanoff, 1981). Therefore, this active-oxygen-generating system is useful for studying the role of active oxygen, particularly ${ }^{\circ} \mathrm{OH}$ and ${ }^{\prime} \mathrm{O}_{2}$, in the intracellular killing of microorganisms in phagocytic cells.

Ahbretiations: SOD. superoxide dismutase: XO, xanthine oxidase: XOA, xanthine oxidase-acetaldehyde 
There are reports dealing with the antimicrobial activity of active oxygen in cell-free systems against Staph. aureus (Klebanoff, $1982 a$; Richmond et al., 1981; Rister \& Baehner, 1976; Rosen \& Klebanoff, 1979a), Escherichia coli (Gregory et al., 1973), Candida (Sasada \& Johnston, 1980), Legionella pneumophila (Locksley et al., 1982) and Nocardia asteroides (Filice et al., 1980; Filice, 1983 ) as targets. However, no comparative study exists of the sensitivity of various organisms to active-oxygen-generating systems. In the present paper, we compare the sensitivity of $E$. coli and Staph. aureus (extracellular parasites), and of Listeria monocytogenes, Salmonella typhimurium, Mycobacterium tuberculosis and Candida albicans (intracellular parasites), to the XOA-FeEDTA system.

\section{METHODS}

Organisms. The following microbial strains were used (source in parentheses): Escherichia coli 81 and Staphylococcus aureus Smith (A. Matsumae, Kitasato Institute, Tokyo, Japan); Listeria monocytogenes EGD (K. Takeya, Kyushu University, Fukuoka, Japan); Salmonella typhimurium HKB-I and Candida albicans NIH A207 (M. Kuwabara, Hiroshima Prefectural Hospital, Hiroshima, Japan); C. guilliermondii ATCC 9058, C. krusei Nagao 7493, C. parapsilosis ATCC 6295, C. pseudotropicalis IFO 0942, C. stellatoidea IFO 0692 and C. tropicalis IFO 0618 (S. Kodaira, Yakult Central Institute for Microbiological Research, Tokyo); Mycobacterium tuberculosis $\mathrm{H}_{37} \mathrm{Rv}, M$. kansasii ATCC 12478, M. intracellulare ATCC 13950 and $M$. chelonei subsp. abscessus ATCC 19977 (A. Y. Tsang, National Jewish Hospital and Research Center, Denver, Colorado, USA).

Chemicals. Xanthine oxidase (XO) (grade III), superoxide dismutase (SOD) (type I), catalase (from bovine liver, thymol-free), cytochrome $c$ (type III) and horseradish peroxidase (type II) were purchased from Sigma. Acetaldehyde was purchased from Merck. All other chemicals were purchased from Wako Pure Chemical.

Assay for antimicrobial activity of the XOA-Fe-EDTA system. E. coli, Staph. aureus, L. monocytogenes and $S$. typhimurium were cultured in tryptosoy broth (Eiken Chemical Co.), with occasional shaking, at $37^{\circ} \mathrm{C}$ for $18 \mathrm{~h}$. Candida spp. were cultured in Sabouraud dextrose broth (Eiken) at $37^{\circ} \mathrm{C}$ for $2 \mathrm{~d}$ and Mycobacterium spp. in Dubos Tween-albumin medium (Eiken) at $37^{\circ} \mathrm{C}$ for 3-7 d. Cells were harvested by centrifugation $(1000 \mathrm{~g}, 15 \mathrm{~min})$, washed twice with $0.1 \mathrm{M}$-sodium sulphate, and suspended in $0.1 \mathrm{M}$-sodium phosphate buffer $(\mathrm{pH} 7.0)$ or $0.2 \mathrm{M}$ sodium acetate buffer ( $\mathrm{pH} 5 \cdot 5$ ). The $\mathrm{OD}_{540}$ of the microbial suspension was adjusted to the desired values using a Hitachi model 100-10 spectrophotometer. The reaction mixture $(2 \mathrm{ml})$, consisting of $20 \mu \mathrm{g} \mathrm{XO} \mathrm{ml} \mathrm{I}^{-1}, 10 \mathrm{mM}$ acetaldehyde, 0-1 mM-ferrous sulphate, 0-1 mM-EDTA and microbial suspension $\left(5 \times 10^{5} \mathrm{ml}^{-1}\right)$ in $38 \mathrm{~mm}$-sodium phosphate (pH 7.0) or $40 \mathrm{~mm}$-sodium acetate buffer (pH 5.5) was incubated at $37^{\circ} \mathrm{C}$ with shaking for $60 \mathrm{~min}$. The resultant microbial suspension was then serially diluted 10 -fold with $0.15 \mathrm{M}$-saline, and the number of c.f.u. was determined on tryptosoy agar (Eiken) for E. coli, Staph. aureus, L. monocytogenes and S. typhimurium, Sabouraud dextrose agar (Eiken) for Candida species and Middlebrook 7H10 agar (Difco) for mycobacteria.

Antimicrobial effect of $\mathrm{H}_{2} \mathrm{O}_{2}$. Organisms suspended in $0.1 \mathrm{M}$-sodium phosphate buffer ( $\mathrm{pH} 7 \cdot 0$ ) containing various concentrations of $\mathrm{H}_{2} \mathrm{O}_{2}$ (determined by absorbance at $230 \mathrm{~nm}$ ) were incubated with shaking in a water bath at $37^{\circ} \mathrm{C}$ for $1 \mathrm{~h}$. The number of c.f.u. was determined as mentioned above.

Measurement of active oxygen concentration. $\mathrm{OH}$ production in the XOA-Fe-EDTA system was assayed by the method of Richmond et al. (1981). Briefly, the reaction mixture (4 ml), containing 2.5 mM-sodium salicylate,

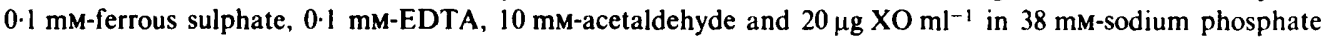
buffer ( $\mathrm{pH} \mathrm{7.0)}$, was incubated with shaking at $37^{\circ} \mathrm{C}$ for $60 \mathrm{~min}$. After incubation, $60 \mu \mathrm{l} 11.6 \mathrm{M}-\mathrm{HCl}$ was added and cold diethyl ether extraction carried out. The extract was dissolved in $1 \mathrm{ml}$ cold double-distilled water, to which $0.13 \mathrm{ml} 10 \%(\mathrm{w} / \mathrm{v})$ trichloroacetic acid in $0.5 \mathrm{M}-\mathrm{HCl}, 0.25 \mathrm{ml} 10 \%(\mathrm{w} / \mathrm{v})$ sodium tungstate and $0.25 \mathrm{ml} 0.5 \%(\mathrm{w} / \mathrm{v})$ sodium nitrite were added. The preparation was left to stand for $5 \mathrm{~min}, 2 \mathrm{ml} 0.5 \mathrm{M}-\mathrm{KOH}$ was added and the $A_{510}$ measured. An appropriate standard curve was prepared using 2,3-dihydroxybenzoate.

$\mathrm{H}_{2} \mathrm{O}_{2}$ production was measured by oxidation of phenol red according to Pick \& Keisari (1980). The reaction mixture ( $4 \mathrm{ml}$ ), containing $0.25 \mathrm{~mm}$-phenol red, $50 \mu \mathrm{g}$ horseradish peroxidase $\mathrm{ml}^{-1}, 10 \mathrm{~mm}$-acetaldehyde and $20 \mu \mathrm{g}$ $\mathrm{XO} \mathrm{m} \mathrm{m}^{-1}$ in $38 \mathrm{mM}$-sodium phosphate buffer $(\mathrm{pH} 7.0)$, was incubated with shaking at $37^{\circ} \mathrm{C}$ for $60 \mathrm{~min}$. After incubation, $0.1 \mathrm{ml} 1 \mathrm{M}-\mathrm{NaOH}$ was added, and after boiling for $3 \mathrm{~min}$, oxidation of phenol red was quantified spectrophotometrically at $610 \mathrm{~nm}$.

The assay of $\mathrm{O}_{2}^{-}$was based on its ability to reduce cytochrome $c$, according to the method of Babior et al. (1973). The reaction mixture $(2 \mathrm{ml})$, containing $160 \mu \mathrm{M}$-cytochrome $c, 60 \mu \mathrm{g}$ catalase $\mathrm{ml}^{-1}, 10 \mathrm{mM}$-acetaldehyde and $20 \mu \mathrm{g}$ $\mathrm{XO} \mathrm{ml^{-1 }}$ in $38 \mathrm{~mm}$-sodium phosphate buffer (pH 7.0), was incubated with shaking at $37^{\circ} \mathrm{C}$ for $60 \mathrm{~min}$. and then reduction of cytochrome $c$ was quantified spectrophotometrically at $550 \mathrm{~nm}$.

Measurement of endogenous SOD and catalase. Organisms were harvested by centrifugation (1000 g. $15 \mathrm{~min})$, washed and suspended in $0.15 \mathrm{M}$-saline. The microbial cells were disrupted with an ultrasonic disintegrator (Insonator, model $200 \mathrm{M}$, Kubota Shoji Co.) at $2 \mathrm{~A}$ for $2 \mathrm{~min}$ and centrifuged at $20000 \mathrm{~g}$ for $15 \mathrm{~min}$. The supernate 
was assayed for SOD and catalase, and its protein concentration was determined by the Lowry method. The assay for SOD, as described by Rister \& Baehner (1976), was based on the capacity of SOD to inhibit cytochrome $c$ reduction mediated by $\mathrm{O}_{2}^{-}$generated in the XOA system. The reaction mixture $(2 \mathrm{ml})$, consisting of $5 \mathrm{~mm}-$ acetaldehyde, $40 \mu \mathrm{g} \mathrm{XO} \mathrm{ml} \mathrm{m}^{-1}, 60 \mu \mathrm{g}$ catalase $\mathrm{ml}^{-1}$ and microbial cell extract in $50 \mathrm{~mm}$-sodium phosphate buffer (pH 7.8), was incubated at $25^{\circ} \mathrm{C}$, and the change in the $A_{5 s u}$ was recorded. Bovine SOD was used as a standard. Catalase was assayed spectrophotometrically by the method of Beers \& Sizer (1952). The reaction mixture ( $2 \mathrm{ml})$, consisting of $15 \mathrm{mM}-\mathrm{H}_{2} \mathrm{O}_{2}$ and microbial cell extract in $50 \mathrm{~mm}$-sodium phosphate buffer $(\mathrm{pH} 7 \cdot 0)$, was incubated at $25^{\circ} \mathrm{C}$, and the change in $A_{240}$ was recorded. Bovine catalase was used as a standard.

\section{RESULTS}

\section{Antimicrobial activity of the XOA-Fe-EDTA system}

Table 1 shows representative results (similar experiments were done at least four times) on the microbicidal activity of the XOA system supplemented with a fixed concentration $(100 \mu \mathrm{M})$ of EDTA and varying concentrations of $\mathrm{Fe}^{2+}$ at $\mathrm{pH} 7 \cdot 0$ and $5 \cdot 5$.

Although the XOA system alone exhibited little microbicidal activity against the test organisms, the activity was markedly augmented by simultaneous addition of EDTA and $\mathrm{Fe}^{2+}$. At pH 7.0, E. coli, Staph. aureus, L. monocytogenes and $S$. typhimurium were killed in the presence of $10-1000 \mu \mathrm{M}-\mathrm{Fe}^{2+} ; 100 \mu \mathrm{M}-\mathrm{Fe}^{2+}$ (equimolar to the EDTA) was optimum for the expression of microbicidal activity. Similar results were obtained in the XOA-Fe-EDTA system at pH 5.5, except for the following. First, Staph. aureus, L. monocytogenes and $S$. typhimurium were more readily killed at the optimum concentration of $\mathrm{Fe}^{2+}(100 \mu \mathrm{M})$ at $\mathrm{pH} 5.5$ than at $\mathrm{pH} 7 \cdot 0$. Second, excess amounts of $\mathrm{Fe}^{2+}$ over $100 \mu \mathrm{M}$ caused a more marked reduction in the activity of the antimicrobial system at $\mathrm{pH} 5 \cdot 5$ than at $\mathrm{pH} 7 \cdot 0$.

The XOA-Fe-EDTA system failed to kill any of the Mycobacterium or Candida species tested (see Methods), even in the presence of an optimum dose of $\mathrm{Fe}^{2+}$, at $\mathrm{pH} 7.0$ or $\mathrm{pH} 5.5$.

Table 1. Microbicidal effects of active oxygen species in the XOA system at $p H 7.0$ and pH 5.5

The organisms $\left(5 \times 10^{5} \mathrm{ml}^{-1}\right)$ were incubated in the XOA system $(2 \mathrm{ml})$ at $\mathrm{pH} 7.0(a)$ or $5.5(b)$, with or without $\left[00 \mu \mathrm{M}-\right.$ EDTA and with various concentrations of $\mathrm{Fe}^{2+}$. Numbers of surviving organisms after $60 \mathrm{~min}$ incubation were counted. The results are means of two determinations \pm the range.

\begin{tabular}{|c|c|c|c|c|c|c|c|c|}
\hline \multirow{2}{*}{$\begin{array}{c}\mathrm{O}_{2}^{-}- \\
\text {generating } \\
\text { system }\end{array}$} & \multicolumn{2}{|c|}{ Addition } & \multicolumn{6}{|c|}{ Survival [ $\log$ (c.f.u. per incubation mixture)] } \\
\hline & EDTA & $\begin{array}{l}\mathrm{Fe}^{2+} \\
(\mu \mathrm{M})\end{array}$ & $\begin{array}{l}\text { Staph. } \\
\text { aureus }\end{array}$ & $\begin{array}{l}\text { L. monocyto- } \\
\text { genes }\end{array}$ & E. coli & $\begin{array}{l}\text { S. typhi- } \\
\text { murium }\end{array}$ & $\begin{array}{l}\text { M. tuber- } \\
\text { culosis }\end{array}$ & C. albicans \\
\hline \multicolumn{9}{|c|}{ (a) Incubation at $\mathrm{pH} 7 \cdot 0$} \\
\hline$-*$ & - & - & $5.91 \pm 0.01$ & $5.44 \pm 0.02$ & $5.78 \pm 0.01$ & $5.94 \pm 0.01$ & $5.64 \pm 0.01$ & $5.45 \pm 0.01$ \\
\hline $\mathrm{XOA}$ & - & - & $5.72 \pm 0.20$ & $5.25 \pm 0.07$ & $5.69 \pm 0.10$ & $5.78 \pm 0.15$ & $5.53 \pm 0.01$ & $5.42 \pm 0.01$ \\
\hline $\mathrm{XOA}$ & + & - & $5.52 \pm 0.07$ & $5.32 \pm 0.02$ & $5.49 \pm 0.02$ & $5.56 \pm 0.01$ & $5 \cdot 52 \pm 0.10$ & $5.47 \pm 0.01$ \\
\hline $\mathrm{XOA}$ & + & 1 & $5.27 \pm 0.01$ & $5.13 \pm 0.05$ & $4.60 \pm 0.01$ & $5.63 \pm 0.04$ & $5 \cdot 35 \pm 0.14$ & $5.46 \pm 0.01$ \\
\hline $\mathrm{XOA}$ & + & 10 & $5 \cdot 16 \pm 0.04$ & $4.88 \pm 0.04$ & $1.69 \pm 0.07$ & $5 \cdot 22 \pm 0.04$ & $5.52 \pm 0.05$ & $5.45 \pm 0.01$ \\
\hline $\mathrm{XOA}$ & + & $10^{2}$ & $3 \cdot 70 \pm 0$ & $2 \cdot 40 \pm 0.11$ & $\overline{0}$ & $2.56 \pm 0.32$ & $5.46 \pm 0.01$ & $5.40 \pm 0.01$ \\
\hline $\mathrm{XOA}$ & + & $10^{3}$ & $3.81 \pm 0.12$ & $2.25 \pm 0.01$ & 0 & $2.57 \pm 0.24$ & $5.40 \pm 0.03$ & $5 \cdot 45 \pm 0$ \\
\hline \multicolumn{9}{|c|}{ (b) Incubation at pH 5.5} \\
\hline$-*$ & - & - & $5 \cdot 60 \pm 0$ & $5.83 \pm 0.02$ & $5.68 \pm 0.01$ & $5.88 \pm 0$ & $5.41 \pm 0.07$ & $5.89 \pm 0.02$ \\
\hline $\mathrm{XOA}$ & - & - & $5.59 \pm 0.06$ & $5.46 \pm 0.31$ & $5.60 \pm 0.04$ & $5.84 \pm 0.03$ & $5.32 \pm 0.06$ & $5.77 \pm 0.05$ \\
\hline XOA & + & - & $5.59 \pm 0.07$ & $5.73 \pm 0.13$ & $5.65 \pm 0.04$ & $5.82 \pm 0.02$ & $5 \cdot 40 \pm 0$ & $5.73 \pm 0.02$ \\
\hline $\mathrm{XOA}$ & + & 1 & $4 \cdot 21 \pm 0.10$ & $5 \cdot 40 \pm 0.02$ & $3.56 \pm 0.05$ & $4.37 \pm 0.09$ & $5.33 \pm 0.07$ & $5.69 \pm 0.06$ \\
\hline $\mathrm{XOA}$ & + & 10 & $4.52 \pm 0.20$ & $5.08 \pm 0.20$ & $3.50 \pm 0.02$ & $4.32 \pm 0.04$ & $5 \cdot 28 \pm 0$ & $5.74 \pm 0.02$ \\
\hline $\mathrm{XOA}$ & + & $10^{2}$ & $2.65 \pm 0.16$ & 0 & 0 & $1.73 \pm 0.03$ & $5.08 \pm 0.03$ & $5.74 \pm 0.02$ \\
\hline XOA & + & $10^{3}$ & $4.92 \pm 0$ & $2.75 \pm 0.04$ & $5 \cdot 30 \pm 0 \cdot 04$ & $5.79 \pm 0.05$ & $5.38 \pm 0.13$ & $5.83 \pm 0.01$ \\
\hline
\end{tabular}


Table 2. Effects of active oxygen scavengers on the bactericidal activity of the XOA-Fe-EDTA system

The organisms $\left(5 \times 10^{5} \mathrm{ml}^{-1}\right)$ were incubated for $60 \mathrm{~min}$ in the XOA-Fe-EDTA system $(100 \mu \mathrm{M}$ each of EDTA and $\mathrm{Fe}^{2+}$ ) in the presence or absence of the indicated scavengers. The activities of SOD and catalase were 2800 and 11000 units (mg protein) $)^{-1}$, respectively. The results are means of two determinations \pm the range.

\begin{tabular}{|c|c|c|c|c|}
\hline \multirow[b]{2}{*}{ Addition } & \multicolumn{4}{|c|}{ Survival rate $(\%)$} \\
\hline & $\begin{array}{l}\text { Staph. } \\
\text { aureus }\end{array}$ & $\begin{array}{l}\text { L. monocyto- } \\
\text { genes }\end{array}$ & E. coli & $\begin{array}{l}\text { S. typhi- } \\
\text { murium }\end{array}$ \\
\hline \multicolumn{5}{|c|}{$\operatorname{SOD}\left(\mu \mathrm{g} \mathrm{ml}^{-1}\right)$} \\
\hline 0 & $<0.1$ & $<0.1$ & $<0.1$ & $<0.1$ \\
\hline 10 & $<0.1$ & $<0.1$ & $<0.1$ & $<0.1$ \\
\hline 100 & $8 \cdot 0 \pm 1 \cdot 4$ & $19 \cdot 0 \pm 3 \cdot 7$ & $56 \cdot 0 \pm 9 \cdot 0$ & $44 \cdot 2 \pm 0.9$ \\
\hline \multicolumn{5}{|c|}{ Catalase $\left(\mu \mathrm{g} \mathrm{ml}^{-1}\right)$} \\
\hline 0 & $1.3 \pm 0.3$ & $0 \cdot 6 \pm 0 \cdot 1$ & $<0.1$ & $<0.1$ \\
\hline 60 & $142.9 \pm 11 \cdot 0$ & $57.7 \pm 3.9$ & $93 \cdot 1 \pm 5 \cdot 2$ & $112.5 \pm 4.7$ \\
\hline 120 & $170.3 \pm 16.5$ & $84 \cdot 6 \pm 5 \cdot 1$ & $101 \cdot 7 \pm 0$ & $114.1 \pm 18.8$ \\
\hline \multicolumn{5}{|c|}{ Mannitol (mM) } \\
\hline 0 & $0.4 \pm 0.1$ & $0 \cdot 4 \pm 0 \cdot 1$ & $<0 \cdot 1$ & $0 \cdot 1 \pm 0$ \\
\hline 10 & $73.4 \pm 0.9$ & $66.7 \pm 1.7$ & $64 \cdot 6 \pm 9 \cdot 2$ & $86.4 \pm 2.0$ \\
\hline 100 & $120.9 \pm 4.2$ & $74 \cdot 2 \pm 0 \cdot 9$ & $81 \cdot 6 \pm 3 \cdot 1$ & $94.2 \pm 0.7$ \\
\hline \multicolumn{5}{|c|}{ Azide (mM) } \\
\hline 0 & $0.5 \pm 0.3$ & $0.7 \pm 0$ & $<0.1$ & $<0 \cdot 1$ \\
\hline 1 & $2.5 \pm 0.1$ & $6.3 \pm 0.8$ & $2 \cdot 6 \pm 0.2$ & $6 \cdot 5 \pm 0 \cdot 1$ \\
\hline 10 & $4.8 \pm 0.5$ & $10 \cdot 1 \pm 0.3$ & $5 \cdot 1 \pm 0.3$ & $7.0 \pm 0.1$ \\
\hline
\end{tabular}

Roles of active oxygen species in the manifestation of antimicrobial activity of the $X O A-F e-E D T A$ system

Table 2 shows effects of various active oxygen-scavengers on killing of test bacteria in the XOA-Fe-EDTA system at pH 7.0. Representative results of four separate experiments are given. Bactericidal activity of the XOA-Fe-EDTA system against these bacteria was markedly inhibited by catalase $\left(\mathrm{H}_{2} \mathrm{O}_{2}\right.$ scavenger) at $60-120 \mu \mathrm{g} \mathrm{ml}^{-1}$ and by mannitol ( $\mathrm{OH}$ scavenger) at $10-100 \mathrm{~mm}$. SOD $\left(\mathrm{O}_{2}^{-}\right.$scavenger $)$showed a lower but significant inhibitory activity against the XOA-Fe-EDTA system: at $50 \mu \mathrm{g} \mathrm{ml}^{-1}$ it led to no appreciable reduction in the activity of the XOA-Fe-EDTA system, but a significant inhibition of the antimicrobial system was seen with $100 \mu \mathrm{g}$ SOD ml-1. In contrast, azide ( ${ }^{1} \mathrm{O}_{2}$ scavenger) had no significant effect on the activity of the XOA-Fe-EDTA system, even at $10 \mathrm{~mm}$. These results indicate that $\mathrm{H}_{2} \mathrm{O}_{2},{ }^{\circ} \mathrm{OH}$ and also $\mathrm{O}_{2}^{-}$ may play an important role in the expression of antimicrobial activity of the XOA-Fe-EDTA system, although mannitol and azide are not strictly specific scavengers of ${ }^{\circ} \mathrm{OH}$ and ${ }^{1} \mathrm{O}_{2}$, respectively. Similar results were also obtained at $\mathrm{pH} 5.5$ (data not shown).

Fig. I shows representative results for the time course of active oxygen production in the XOA-Fe-EDTA system. $\mathrm{O}_{2}^{-}$was generated rapidly $\left(1.1 \mathrm{nmol} \mathrm{min}^{-1} \mathrm{ml}^{-1}\right)$ and reached a plateau at 30 min. Generation of $\mathrm{H}_{2} \mathrm{O}_{2}$, as a result of spontaneous dismutation of $\mathrm{O}_{2}^{-}$, was

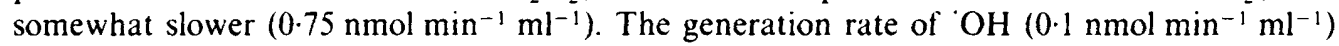
was much less than that of the former species. It should be noted that the apparent $\mathrm{OH}$ generation is less than the actual one, since the ${ }^{\circ} \mathrm{OH}$ radical is very unstable (Babior, 1978). Fig. 2 shows effects of SOD on the generation of $\mathrm{H}_{2} \mathrm{O}_{2}$ and $\mathrm{OH}$ in the XOA and XOA-Fe-EDTA systems (60 min incubation), respectively. The generation of both $\mathrm{H}_{2} \mathrm{O}_{2}$ and $\mathrm{OH}$ significantly increased in the presence of SOD at $10-100 \mu \mathrm{g} \mathrm{ml}^{-1}$. The production of $\mathrm{OH}$ in the $\mathrm{XOA}-\mathrm{Fe}-$ EDTA system was highest when EDTA and $\mathrm{Fe}^{2+}$ were present in approximately equimolar amounts (data not shown). This is consistent with the observation that the antimicrobial activity of the XOA-Fe-EDTA system was greatest when equimolar amounts of EDTA and $\mathrm{Fe}^{2+}$ were added (Table 1). This may suggest that ${ }^{\circ} \mathrm{OH}$ is important in the bactericidal mechanism of the XOA-Fe-EDTA system. 


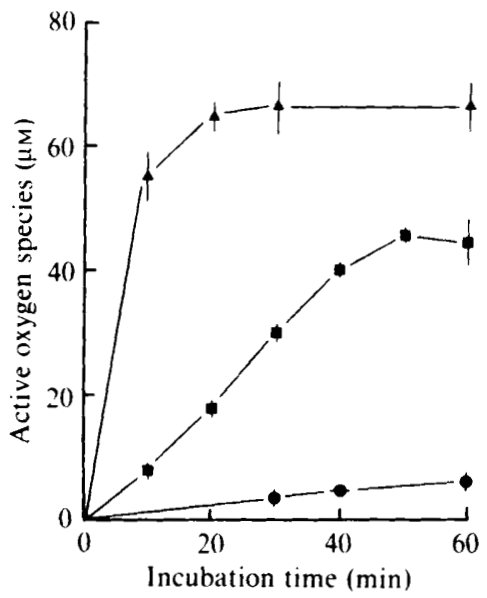

Fig. 1

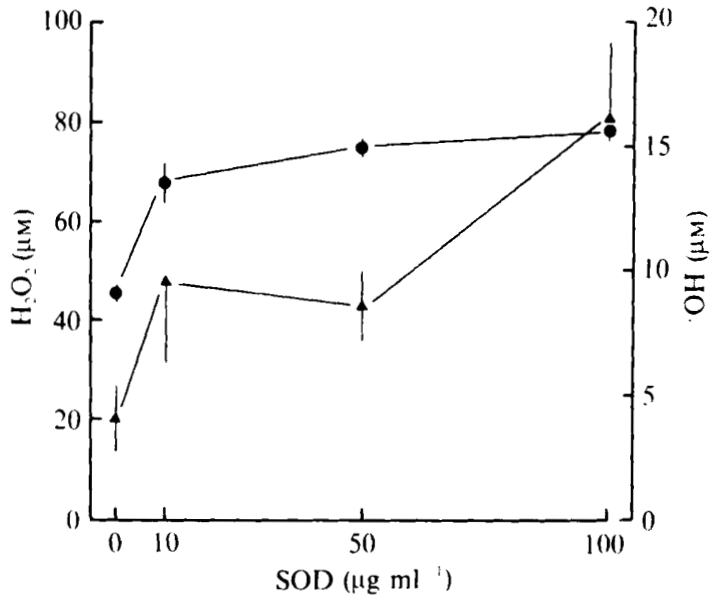

Fig. 2

Fig. 1. Generation of active oxygen species in the XOA-Fe-EDTA system. Generation of $\mathrm{O}_{2}^{-}(\boldsymbol{\Delta})$ and of $\mathrm{H}_{2} \mathrm{O}_{2}(\square)$ in the XOA system alone, and that of $\mathrm{OH}(\mathrm{O})$ in the XOA system supplemented with $100 \mu \mathrm{M}$ each of $\mathrm{Fe}^{2+}$ and EDTA, were measured as described in Methods. Each point indicates the mean \pm the range $(n=2)$ (a horizontal bar indicates that the results were identical).

Fig. 2. Effect of SOD on the generation of active oxygen species in the XOA and XOA-Fe-EDTA systems. $\mathrm{H}_{2} \mathrm{O}_{2}(\mathrm{O})$ and $\mathrm{OH}(\Delta)$ were generated in the XOA and XOA-Fe-EDTA systems $(100 \mu \mathrm{M}$ each of $\mathrm{Fe}^{2+}$ and EDTA) containing SOD at the indicated concentrations, respectively. Each point indicates the mean \pm the range $(n=2)$.

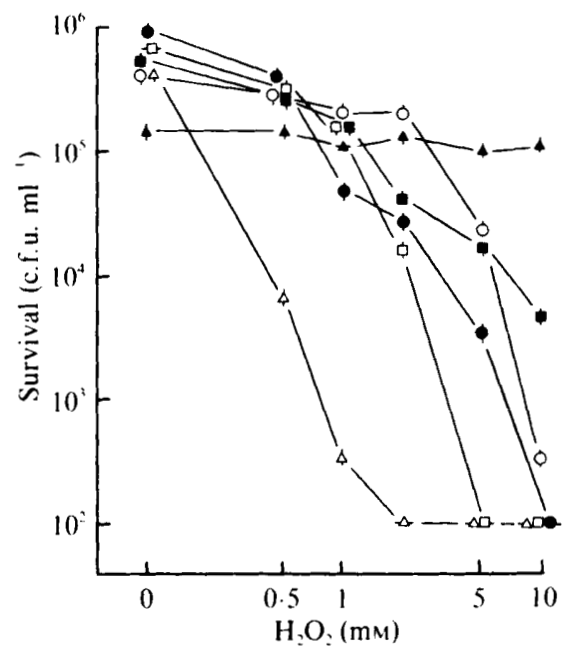

Fig. 3. Antimicrobial activity of $\mathrm{H}_{2} \mathrm{O}_{2}$ against L. monocytogenes $(O)$, Staph. aureus $(\triangle)$. E. coli $(\square), S$. typhimurium (O), C. albicans ( $(\mathbf{)})$ and $M$. tuberculosis $(\triangle)$. For details see Methods. Each point indicates the mean \pm the range $(n=2)$ (a horizontal bar indicates that the results were identical).

Fig. 3 shows the antimicrobial activity of $\mathrm{H}_{2} \mathrm{O}_{2}$. Staph. aureus, E. coli. S. typhimurium, L. monocytogenes and $C$. albicans were sensitive to $\mathrm{H}_{2} \mathrm{O}_{2}$ and almost completely destroyed by $\mathrm{H}_{2} \mathrm{O}_{2}$ at concentrations above $5 \mathrm{mM}$. In contrast, $M$. tuberculosis was resistant to $\mathrm{H}_{2} \mathrm{O}_{2}$, even at $10 \mathrm{~mm}$. However, it should be noted that all the test organisms, except Staph. aureus, were resistant to $0.5 \mathrm{mM}-\mathrm{H}_{2} \mathrm{O}_{2}$ and that this amount is nearly ten times the concentration of $\mathrm{H}_{2} \mathrm{O}_{2}$ accumulated in the XOA-Fe-EDTA system during the $60 \mathrm{~min}$ incubation (Figs 1 and 2). 
Table 3. Content of endogenous scavengers in the test organisms

\begin{tabular}{lrr} 
& \multicolumn{2}{c}{$\begin{array}{c}\text { Peroxidase-catabolizing enzyme* } \\
\text { [units (mg protein) }\end{array}$} \\
\cline { 2 - 3 } \multicolumn{1}{c}{ Organism } & \multicolumn{1}{c}{ SOD } & Catalase \\
E. coli & $12.8 \pm 0.3$ & $6.7 \pm 1.2$ \\
Staph. aureus & $12.1 \pm 1.4$ & $60.0 \pm 4.3$ \\
L. monocytogenes & $39.7 \pm 5.1$ & $113.3 \pm 12.3$ \\
S. typhimurium & $12.1 \pm 1.5$ & $6.0 \pm 0.5$ \\
M. tuberculosis & $5.5 \pm 0.3$ & $0.8 \pm 0.1$ \\
C. albicans & $61.0 \pm 9.0$ & $1.9 \pm 0.4$
\end{tabular}

* The results are means \pm standard error $(n=3)$.

\section{Amount of endogenous active oxygen-scavengers in the test organisms}

Table 3 shows the content of endogenous active oxygen-scavengers in the organisms used in this study. C. albicans, which was resistant to the XOA-Fe-EDTA system, had the highest content of SOD, followed by L. monocytogenes. Although $M$. tuberculosis had the least SOD, it was resistant to the XOA-Fe-EDTA system (Table 1). The catalase content differed markedly from species to species (Table 3). There was no statistical correlation (Student's $t$ test, $P \geqslant 0 \cdot 1$ ) between the content of SOD or catalase of a given microbe and its susceptibility to the XOA-FeEDTA system. Indeed, $C$. albicans and $M$. tuberculosis, resistant to the XOA-Fe-EDTA system, had a much lower content of catalase than the other organisms. Also there was no significant difference in the content of endogenous scavengers between the intra- and extracellular parasites.

\section{DISCUSSION}

The XOA-Fe-EDTA system has been used as a model of oxygen-dependent bactericidal mechanisms of phagocytes (Rosen \& Klebanoff, 1979a). The XOA system generates $\mathrm{O}_{2}^{-}$and $\mathrm{H}_{2} \mathrm{O}_{2}$ and, in the presence of iron-EDTA, also ${ }^{\circ} \mathrm{OH}$ and ${ }^{1} \mathrm{O}_{2}$ (Rosen \& Klebanoff, 1981). This system had a potent microbicidal effect on all the organisms tested in the present study, except for $C$. albicans and $M$. tuberculosis. $\mathrm{H}_{2} \mathrm{O}_{2}$ at the concentration achieved in the XOA system (about $50 \mu \mathrm{M}$ ) failed to kill any of the organisms except Staph. aureus (Fig. 3), suggesting that $\mathrm{H}_{2} \mathrm{O}_{2}$ is unlikely to play a central role in the XOA-Fe-EDTA system as an effector molecule. However, the role of $\mathrm{H}_{2} \mathrm{O}_{2}$ in this microbicidal system cannot be excluded, because the microbicidal activity of $\mathrm{H}_{2} \mathrm{O}_{2}$ is known to increase when $\mathrm{H}_{2} \mathrm{O}_{2}$ is continuously generated (Klebanoff, 1969). As shown in Table 1, both bactericidal activity and production of ${ }^{\circ} \mathrm{OH}$ in the $\mathrm{XOA}-\mathrm{Fe}-\mathrm{EDTA}$ system were highest in the presence of equimolar amounts of $\mathrm{Fe}^{2+}$ and EDTA. This suggests that the $\mathrm{OH}$ radical is one of the important species in the bactericidal mechanism of the XOA-Fe-EDTA system. However, the finding that $\mathrm{OH}$ generation in the XOA-FeEDTA system increased two- to fourfold in the presence of SOD at $10-100 \mu \mathrm{g} \mathrm{ml}^{-1}$ (Fig. 2) is inconsistent with the observation that $100 \mu \mathrm{g} \mathrm{SOD} \mathrm{ml}^{-1}$ caused a significant reduction in the microbicidal activity of the system (Table 2). Thus, it seems that not only ${ }^{\circ} \mathrm{OH}$ but also $\mathrm{O}_{2}^{-}$can play an important role in the microbicidal system. The reduction in the bactericidal activity of the XOA-Fe-EDTA system by catalase may be attributed to the almost complete removal of $\mathrm{H}_{2} \mathrm{O}_{2}$ by the enzyme, hence a cessation of ${ }^{\circ} \mathrm{OH}$ generation.

The present observations indicate an important role for $\mathrm{OH}$ in the microbicidal mechanisms of our XOA-Fe-EDTA system. ${ }^{\circ} \mathrm{OH}$ is also thought to be important in the intracellular killing of bacteria by macrophages and polymorphonuclear leucocytes, in which XOA and EDTA may be replaced by NADPH oxidase-NADPH and probably tryptophan or ADP as an iron-chelating agent, respectively (Oyanagui, 1981). There are reports that the ${ }^{\circ} \mathrm{OH}$ radical participates in the oxygen-dependent microbial killing of these phagocytic cells (Babior, 1978; Hoidal et al., 1979; Rosen \& Klebanoff, 1979b), although other investigators have proposed an important role for 
$\mathrm{O}_{2}^{-}$(Yost \& Fridovich, 1974), $\mathrm{H}_{2} \mathrm{O}_{2}$ (Boveris et al., 1980; Dockrell \& Playfair, 1984; Murray et al., 1980; Murray, 1981), and ${ }^{\prime} \mathrm{O}_{2}$ (Krinsky, 1974) as direct effector molecules against microorganisms rather than $\mathrm{OH}$, since $\mathrm{OH}$ is too unstable to pass through the cell wall into the cytoplasm.

We found no tendency for the intracellular parasites to be more resistant to the direct toxic effect of active oxygen radicals. However, Mycobacteria and Candida species were completely resistant. Active oxygen species presumably oxidize certain essential proteins or enzymes (Chance et al., 1979). Mycobacteria contain abundant lipid, and lipid content correlates well with their resistance to active oxygen radicals (Goren et al., 1974a, b). Therefore, these lipids in the mycobacterial cell wall may be able to trap toxic active oxygen radicals before any oxidation of membrane proteins occurs. If so, this may account for the high resistance of Candida species to the XOA-Fe-EDTA system; $C$. albicans also has a relatively large amount of lipid in its cell surface (Sato et al., 1968).

Although there are reports that the endogenous scavenger (SOD and catalase) content of bacteria correlates with their resistance to active oxygen species (Amin \& Olson, 1968; Gregory et al., 1973; Howard, 1981; Mandell, 1975; Murray et al., 1980; Murray, 1981), our results are closer to the observations of Filice et al. (1980), Filice (1983) and Gangadharam \& Pratt (1984), who found that the SOD and catalase contents of Nocardia asteroides, $M$. intracellulare and $M$. tuberculosis did not correlate with their resistance to killing by $\mathrm{H}_{2} \mathrm{O}_{2}$ or by the lactoperoxidase- $\mathrm{H}_{2} \mathrm{O}_{2}$-iodide system. In addition, we found no obvious difference between intra- and extracellular parasites, in terms of their oxygen scavenger content. The level of endogenous scavengers for active oxygen species is probably not the only factor determining the sensitivity of a micro-organism to active oxygen species.

\section{REFERENCES}

Amin, V. M. \& Olson, N. F. (1968). Influence of catalase activity on resistance of coagulase-positive staphylococci to hydrogen peroxide. Applied Microbiology 16, 267-270.

BABIOR, B. M. (1978). Oxygen-dependent microbial killing by phagocytes. New England Journal of Medicine 298, 659-668.

Babior, B. M., Kipnes, R. S. \& Curnutte, J. T. (1973). The production by leukocytes of superoxide, a potential agent. Journal of Clinical Investigation 52, 741-744.

BEERS, R. F., JR \& SIZER, I. W. (1952). A spectrophotometric method for measuring the breakdown of hydrogen peroxide by catalase. Journal of Biological Chemistry 195, 133-140.

Boveris, A., Sies, H., Martino, E., Docampo, R., Turrens, J. F. \& Stoppani, A. O. M. (1980). Deficient metabolic utilization of hydrogen peroxide in Trypanosoma cruzi. Biochemical Journal 188, 643648.

Chance, B., Sies, H. \& Boveris, A. (1979). Hydroperoxide metabolism in mammalian organs. Physiological Reviews 59, 527-605.

Dath, D. B. \& Karnovsky, M. L. (1975). Superoxide production by phagocytic leukocytes. Journal of Experimental Medicine 141, 257-262.

Dockrell, H. M. \& Playfair, J. H. (1984). Killing of Plasmodium yoelii by enzyme-induced products of the oxidative burst. Infection and Immunity 43, 451456.

ElSBACH, P. \& WeISS, J. (1983). A reevaluation of the roles of the $\mathrm{O}_{2}$-dependent and $\mathrm{O}_{2}$-independent microbicidal systems of phagocytes. Reviews of Infectious Disease 5, 843-853.

FILICE, G. A. (1983). Resistance of Nocardia asteroides to oxygen-dependent killing by neutrophils. Journal of Infectious Diseases 148, 861-867.

Filice, G. A., Beaman, B. L., Krick, J. A. \& REMington, J. S. (1980). Effects of human neutrophils and monocytes on Nocardia asteroides: failure of killing despite occurrence of the oxidative metabolic burst. Journal of Infectious Diseases 142 , 432-438.

Gangadharam, P. R. J. \& Pratt, P. F. (1984). Susceptibility of Mycobacterium intracellulare to hydrogen peroxide. American Review of Respiratory Diseases 130, 309-311.

Goren, M. B., BRoKL, O. \& SChaEFER, W. B. (1974a). Lipids of putative relevance to virulence in Mycobacterium tuberculosis: correlation of virulence with elaboration of sulfatides and strongly acidic lipids. Infection and Immunity 9, 142-149.

GoReN, M. B., BROKL, O. \& SCHAEFER, W. B. (1974b). Lipids of putative relevance to virulence in $M y c o b a c$ terium tuberculosis: phthiocerol dimycocerosate and attenuation indicator lipid. Infection and Immunity 9 , $150-158$.

Gregory, E. M., Yost, F. J., JR \& Fridovich, I. (1973). Superoxide dismutase of Escherichia coli: intracellular localization and functions. Journal of Bacteriology 115, 987-991.

Halliwell, B. (1976). An attempt to demonstrate a reaction between superoxide and hydrogen peroxide. FEBS Letters 72, 8-10.

Halliwell, B. (1978a). Superoxide-dependent formation of hydroxyl radicals in the presence of iron chelates. FEBS Letters 92, 321-326.

Halliwell, B. $(1978 b)$. Superoxide-dependent formation of hydroxyl radicals in the presence of iron salts. FEBS Letters 96, 238-242. 
hoidal, J. R.. Beall, G. D. \& Repine, J. E. (1979). Production of hydroxyl radical by human alveolar macrophages. Infection and Immunity 26. $1088-1092$.

HowARD. D. H. (1981). Comparative sensitivity of Histoplasma capsulatum conidiospores and blastospores to oxidative antifungal systems. Infection and Immunity 32. 381-387.

Kanai, K. \& Kondo, E. (1979). Antibacterial and cytotoxic aspects of long-chain fatty acids as cell surface events: selected topics. Japanese Journal of Medical Science and Biology 32, 135-174.

KLEBANOFF. S. J. (1967). Iodination of bacteria: a bactericidal mechanism. Journal of Experimental Medicine 126. 1063-1079.

KLEBANOFF. S. J. (1968). Myeloperoxidase halide hydrogen peroxide antibacterial system. Journal of Bacteriology 95, 2131-2138.

KLEBANOFF, S. J. (1969). Antimicrobial activity of catalase at acid $\mathrm{pH}$. Proceedings of the Society for Experimental Biologl and Medicine 132, 571-574.

KlebanofF, S. J. (1982a). The iron $\mathrm{H}_{2} \mathrm{O}_{2}$-iodide cytotoxic system. Journal of Experimental Medicine 156, 1262-1267.

KLEBANOFF, S. J. (1982h). Iodination catalyzed by the xanthine oxidase system: role of hydroxyl radicals. Biochemistry 21, 4110-4116.

K lebanoff, S. J. \& Shepard, C. C. (1984). Toxic effect of the peroxidase hydrogen peroxide-halide antimicrobial system on Mycohacterium leprae. Infection and Immunity 44, 534-536.

KRINSKY, N. I. (1974). Singlet excited oxygen as a mediator of the antibacterial action of leukocytes. Science 186. 363-365.

LOCKSLEY, R. M., JACOBS, R. F, WILSON, C. B., WEAVER, W. M. \& KLEBanofF, S. J. (1982). Susceptibility of Legionella pneumophila to oxygendependent microbicidal system. Journal of Immunology 129. 2192-2197.

MANDELl. G. (1975). Catalase, superoxide dismutase, and virulence of Staphylococcus aureus : in ritro and in vivo studies with emphasis on staphylococcal leukocyte interaction. Journal of Clinical Investigation 55. $561 \cdot 566$.

MurRay, H. W. (1981). Susceptibility of Leishmania to oxygen intermediates and killing by normal macrophages. Journal of Experimental Medicine 153, 1302 1315.

Murray, H. W., Nathan, C. F. \& Cohn, Z. A. (1980). Macrophage oxygen-dependent antimicrobial activity. IV. Role of endogenous scavengers of oxygen intermediates. Journal of Experimental Medicine 152. 1610-1624.

Nathan, C. F. (1982). Secretion of oxygen intermediates: role in effector functions of activated macrophages. Federation Proceedings 41. 2206-2211.
Oyanagui, Y. (1981). Superoxide and Medicine. Tokyo: Kyoritsu-Shuppan Co.

PABST, M. J., \& Johnston, R. B., JR (1980). Increased production of superoxide anion by macrophages exposed in vitro to muramyl dipeptide or lipopolysaccharide. Journal of Experimental Medicine 151, 101114.

Pick. E. \& KeISARI, Y. (1980). A simple colorimetric method for the measurement of hydrogen peroxide produced by cells in culture. Journal of Immunological Methods 38, 161-170.

Richmond. R.. Halliwell, B.. Chauhan, J. \& DARBRE, A. (1981). Superoxide-dependent formation of hydroxyl radicals: detection of hydroxyl radicals by the hydroxylation of aromatic compounds. Analytical Biochemistry 118, 328 335.

RISTER, M. \& BAEHNER, R. L. (1976). The alternation of superoxide dismutase, catalase, glutathione peroxidase, and $\mathrm{NAD}(\mathrm{P}) \mathrm{H}$ cytochrome $c$ reductase in guinea pig polymorphonuclear leukocytes and alveolar macrophages during hyperoxia. Journal of Clinical Investigation 58. 1174-1184.

Rosen. H. \& KLfBanofF, S. J. (1979a). Bactericidal activity of superoxide anion-generating system. Journal of Experimental Medicine 149, 27-39

Rosen, H. \& KlebanofF, S. J. (1979b). Hydroxyl radical generation by polymorphonuclear leukocytes measured by electron spin resonance spectroscopy. Journal of Clinical Investigation 64, 1725-1729.

Rosen, H. \& KLEBanOFF. S. J. (1981). Role of iron and ethylenediaminetetraacetic acid in the bactericidal activity of superoxide anion-generating system. Archices of Biochemistry and Biophysics 208, 512-519.

Saito, H.. Tomioka. H. \& Yoneyama, T. (1984). Growth of group IV mycobacteria on medium containing various saturated and unsaturated fatty acids. Antimicrohial Agents and Chemotherapy 26. 164-169.

SASAdA, M. \& Johnston, R. B., JR (1980). Macrophage microbicidal activity: correlation between phagocytosis-associated oxidative metabolism and the killing of Candida by macrophages. Journal of Experimental Medicine 152, 85-98.

Sato, Y., Inomata, N., Hada, S., Oka. K. \& Honda. H. (1968). Studies of the lipid components and their component fatty acids of certain dermatopathogenic fungi. Japanese Journal of Medical Mycology 9. 125 132.

Yost. F. J., JR \& Fridovich, I. (1974). Superoxide radicals and phagocytosis. Archires of Biochemistry and Biophysics 161, 395-401.

Weiss, S. J., King, G. W. \& LoBuglio. A. F. (1977) Evidence for hydroxyl radical generation by human monocytes. Journal of Clinical Intestigation 60, 370373. 